\title{
PENGEMBANGAN POTENSI ATRAKSI WISATA GASTRONOMI DI DESA CILILIN KABUPATEN BANDUNG BARAT
}

\author{
Arfah Sahabudin \\ Prodi Magister Pariwisata Berkelanjutan SPs Universitas Padjadjaran Bandung \\ Email: luluana1.arfah@gmail.com \\ Reiza D. Dienaputra \\ Prodi Magister Pariwisata Berkelanjutan SPs Universitas Padjadjaran Bandung \\ Email: reizaputra@yahoo.com \\ Awaludin Nugraha \\ Prodi Magister Pariwisata Berkelanjutan SPs Universitas Padjadjaran Bandung \\ Email: awaludin.nugraha@unpad.ac.id
}

\begin{abstract}
In Cililin Village, Cililin District, West Bandung Regency, there are several potentials that can be explored and developed as tourist attractions. One of them is the famous wajit Cililin. Wajit Cililin has been produced for a long time and it is sold in the form of its products. However, there is an interesting side that has not been utilised to be developed, namely the manufacturing process. The purpose of this study is to reveal the potential of Cililin assets to be developed into tourist attractions. The research method used is a qualitative method. Primary data collection is conducted by observation and in-depth interviews. Besides that, a literature study is also conducted. Data analysis uses an interactive model, through three activities carried out simultaneously, namely reduction of data, presentation of data, and conclusion. The results showed that the wajit Cililin manufacturing process has the potential to become a gastronomic tourist attraction and educational tourism, since it has interesting uniqueness. The attraction can only be displayed to tourists by local people who have the skill to process and produce it, hence that the development must involve the local community.
\end{abstract}

Keywords: gastronomic tourism, educational tourism, community based tourism. 


\section{Pendahuluan}

Saat ini sektor pariwisata adalah sumber pendapatan tertinggi di Indonesia, seperti yang diutarakan Menteri Pariwisata Arief Yahya pada Jambore Himpunan Pramuwisata Indonesia - Pokdarwis Banten, Carita Februari 2019, "Pariwisata akan menjadi penghasil devisa terbanyak di Indonesia", sehingga menarik untuk mewujudkan pembangunan desa melalui sektor pariwisata dengan menjadikan desa sebagai salah satu tujuan wisata alternatif.

Desa Cililin, terletak di Kecamatan Cililin Kabupaten Bandung Barat Provinsi Jawa Barat. Luas wilayahnya adalah $314.920 \mathrm{Ha} / \mathrm{m} 2$, merupakan daerah dataran rendah dan berbukit dengan ketinggian 800 sampai dengan 1000 meter di atas permukaan laut. Memiliki suhu rata-rata 15 - 22ํㅡ. Jaraknya sekitar 20 km dari Kota Bandung. Pada tahun 2016 jumlah penduduknya 10.858 jiwa yang terdiri dari 5.543 jiwa laki-laki dan 5.315 jiwa perempuan. Desa Cililin terdiri dari 12 RW dan 49 RT dengan 3.110 KK dengan kepadatan penduduk 3.102 per KM. (BPS Kabupaten Bandung Barat, 2017). Potensi desa saat ini dari sektor wisata kuliner, terdapat Saung Apung di sekitar genangan Saguling, yang menyediakan ikan bakar dan makanan kemasan khas seperti wajit Cililin, kerupuk Cililin, Cireng, dan lain-lain yang ada di toko oleh-oleh sepanjang Jalan Raya Cililin dan sekitar Alun-alun Cililin.

Tahun 2015, Menpar menetapkan lima destinasi wisata kuliner unggulan di Indonesia yakni Bandung, Solo, Yogyakarta, Semarang, dan Bali (Kompas.com, 2015). Penetapan tersebut berdasarkan enam kelayakan, yakni produk dan daya tarik utama, pengemasan produk dan event, kelayakan pelayanan, kelayakan lingkungan, kelayakan bisnis, serta peranan pemerintah dalam pengembangan destinasi wisata kuliner. 
Bila Bandung telah menjadi destinasi wisata kuliner unggulan, maka Wajit Cililin yang merupakan makanan khas dan ikon oleh-oleh Kabupaten Bandung Barat yang telah dikenal puluhan tahun, adalah salah satu produk kuliner unggulan di Bandung Barat khususnya di Desa Cililin yang merupakan sentra Wajit Cililin terbesar di Kabupaten Bandung Barat. Umumnya usaha Wajit di Cililin merupakan usaha warisan keluarga secara turun-temurun. Bahan baku utamanya adalah ketan putih, gula kawung atau gula aren dan kelapa yang merupakan bahan-bahan lokal. Seiring kemajuan zaman, untuk menambah cita rasa biasanya mereka menambah bahan lain seperti susu dan mentega. Kemudian ditambah kreatifitas, wajit kini bukan hanya rasa gula aren, tapi sudah memiliki varian rasa yang beragam. Misalnya, Wajit Cililin rasa durian, rasa pandan, rasa coklat, dan ketan hitam.

Namun demikian terdapat faktor-faktor yang diduga menyebabkan kurang berkembangnya desa ini dari sektor pariwisata, antara lain potensi wisata gastronomi yang belum dimanfaatkan secara maksimal. Salah satu penyebabnya adalah keterbatasan sumber daya manusia dan modal, serta mulai berkurangnya ketersediaan bahan baku sehingga harus mengambil dari daerah lain, seperti pembungkus wajit dan gula aren. Rendahnya tingkat pendidikan, serta kurangnya pembinaan pendampingan pada masyarakat mengakibatkan masyarakat kurang memahami serta kurang siap untuk mengemas potensi lainnya menjadi suatu daya tarik wisata yang memiliki keunikan dan kekhasan.

Yang patut dilakukan untuk pelestarian dalam bidang kuliner di Indonesia adalah memelihara, memanfaatkan serta mengembangkan. Memelihara yaitu menjaga kuliner Nusantara sebagaimana aslinya dalam berbagai literatur dari penyajian dengan beragam komponen rasa, bentuk dan tekstur. Kedua, memanfaatkannya terkait dengan kebutuhan tertentu. Ketiga, mengembangkan kuliner Nusantara dengan menambahkan dan memperkaya ide atau gagasan baru untuk dapat dipromosikan ke mancanegara sehingga dapat menjadi salah satu daya 
tarik pariwisata yang mampu menarik minat wisatawan domestik dan wisatawan mancanegara.

Faktor-faktor umum yang dapat menarik wisatawan untuk berwisata kuliner sebagai berikut :

1. Keragaman aktivitas kuliner;

2. Makanan khas;

3. Produk tradisional, nasional dan internasional;

4. Lokasi yang nyaman dan bersih;

5. Desain ruangan (venue) yang unik dan menarik;

6. Lingkungan yang menarik;

7. Pelayanan yang baik;

8. Pasar yang kompetitif;

9. Harga dan proporsi nilai;

10.Peluang bersosialisasi;

11.Interaksi budaya dengan kuliner;

12.Suasana kekeluargaan.

Wisatawan akan menyesuaikan dan menyukai makanan serta minuman tradisional dari tempat wisata yang mereka kunjungi bila dilakukan usaha yang gencar untuk memperkenalkan makanan dan minuman tersebut dengan berbagai kreatifitas (Prasiasa, 2013). Ini termasuk juga menampilkan cara pembuatan makanan sebagai atraksi yang dapat dinikmati oleh wisatawan, yang dapat dijadikan bagian dari paket wisata yang ditawarkan. 
Adapun pertanyaan yang akan dijawab dalam penelitian ini adalah bagaimana upaya mengembangkan Wajit Cililin menjadi daya tarik wisata di Desa Cililin? Serta apa kendalanya?

\section{Metode}

Penelitian ini merupakan penelitian kualitatif. Jenis data yang digunakan adalah jenis data kualitatif, sedangkan sumber data yang digunakan adalah sumber data primer dan sekunder. Pengumpulan data primer dilakukan dengan menggunakan teknik observasi atau pengamatan langsung di lokasi penelitian dan wawancara mendalam (in-deph interview), yaitu peneliti bertanya langsung kepada informan yang dipilih. Pengumpulan data sekunder dilakukan dengan studi pustaka terhadap jurnal-jurnal dan penelitian serupa sebelumnya, serta buku-buku terkait. Dalam penelitian ini teknik penentuan informan menggunakan teknik purposive sampling. Teknik pengambilan purposive sampling adalah teknik penentuan informan dengan pertimbangan tertentu (Sugiyono, 2013). Dalam hal ini informan yang dipilih adalah pengrajin wajit Cililin yang merupakan generasi keempat dari Hj. Romlah. Hj. Romlah sudah memproduksi wajit Cililin dan menjual ke masyarakat sejak tahun 1938.

Analisis data dalam penelitian ini dilakukan melalui tiga kegiatan bersamaan (model interaktif), yaitu reduksi data, display data, dan kesimpulan. Reduksi data merupakan proses pemilihan, pemusatan pada penyederhanaan, pengabstrakan, dan transformasi data "kasar" dengan melakukan pemotongan (rangkum) data, sehingga hanya hal-hal yang pokok yang diambil. Reduksi data bertujuan untuk mempermudah pemahaman terhadap data yang telah terkumpul, sehingga data yang direduksi memberikan gambaran lebih rinci. Display data adalah upaya untuk memberikan gambaran penelitian secara utuh dari data-data hasil penelitian yang sudah tersusun secara terperinci. Data yang terkumpul secara terperinci dan menyeluruh selanjutnya dicari pola hubungannya untuk mengambil kesimpulan 
yang tepat. Penyajian data selanjutnya disusun dalam bentuk uraian atau laporan sesuai dengan diperolehnya hasil penelitian. Kesimpulan merupakan tahap akhir dalam proses penelitian untuk memberikan makna terhadap data yang telah dianalisis (Miles dan Huberman, 1992).

\section{Hasil Penelitian dan Pembahasan}

Wajit adalah nama makanan yang terbuat dari beras ketan, kelapa dan gula aren. Kue Wajit memiliki beberapa sebutan yang berbeda-beda di setiap tempat, seperti Wajik dikenal di daerah Jawa Tengah; di Sumatra disebut Pulut Manis; di Sulawesi disebut Baje; dan di Bandung disebut Wajit.

Makanan tradisional ini biasanya disajikan di acara-acara khusus seperti perayaan hari raya, hajatan, pernikahan atau khitanan, syukuran, hari raya dan sebagainya. Perbedaan khas dari Wajit Cililin sebagai oleh-oleh khas dari Kabupaten Bandung Barat adalah bentuknya mengerucut dan terbungkus cantik oleh daun jagung yang sudah kering.

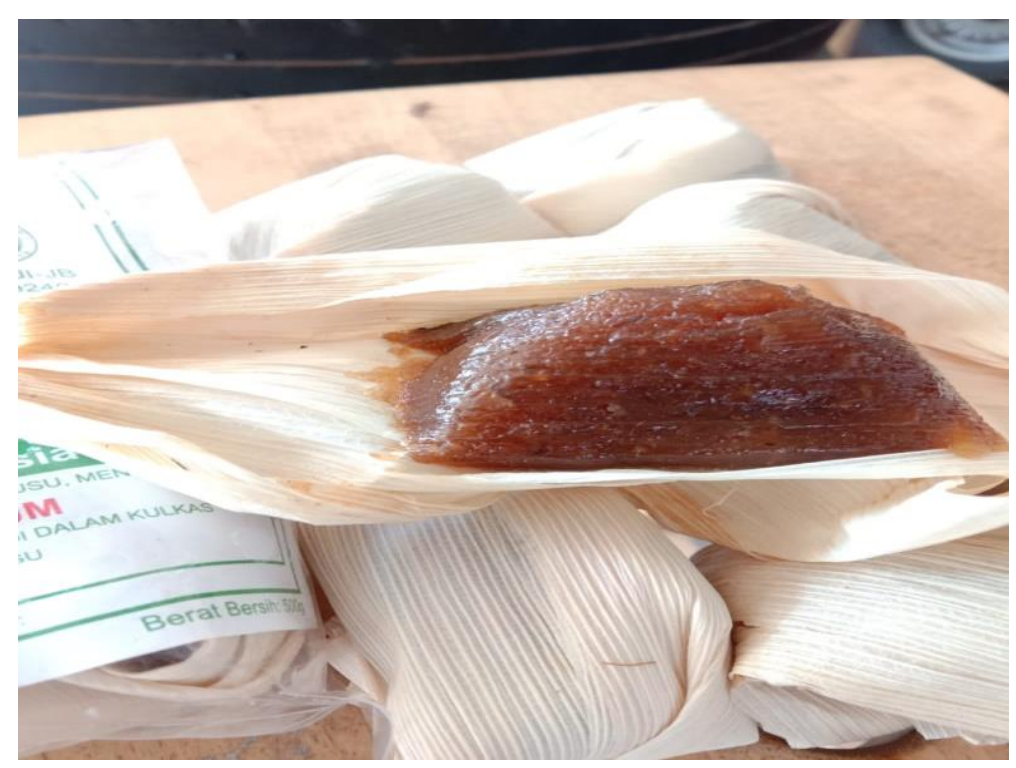

Gambar 1. Wajit Cililin

Sumber : koleksi penulis 
Cililin merupakan salah satu wilayah kecamatan yang ada di Kabupaten Bandung Barat yang mempunyai beragam potensi yang dapat dikembangkan. Salah satunya yang potensial untuk ditingkatkan kontribusinya adalah industri pengolahan Wajit Cililin. Cililin merupakan sentra pembuatan wajit yang ada di Kabupaten Bandung Barat. Masyarakatnya memiliki kemampuan dalam mengolah bahan baku pembuatan wajit menjadi produk jadi. Sentra pembuatan industri wajit di Desa Cililin memiliki 15 unit usaha wajit.

Untuk menuju ke Desa Cililin dari kota Bandung, dapat ditempuh dengan kendaraan pribadi atau pun umum (bus). Jarak yang ditempuh $72 \mathrm{Km}$ dalam kurang lebih 1 jam melalui Padalarang arah Batujajar, atau tol Soreang keluar tol Margaasih menuju selatan sejauh $15 \mathrm{Km}$.

Menurut informan, Juwita dan Uti yang pertama kali membuat penganan yang bernama wajit pada tahun 1916. Nama wajit berasal dari bahasa Jawa yaitu wajik. Kemudian ada perubahan pengucapan atau gejala bahasa dari wajik ke wajit. Setelah Juwita dan Uti meninggal tahun 1936 pembuatan wajit diteruskan oleh anaknya yaitu Siti Romlah yang nama aslinya Irah.

Awalnya pembuatan wajit tersebut untuk dimakan sendiri, akan tetapi banyak warga penasaran akan kelezatan wajit, lalu mulai berdatangan ke rumah Juwita dan Uti untuk mencicipi wajit buatan Juwita dan Uti. Dari situ muncul kebiasaan pagi-pagi atau sore-sore makan wajit dengan teh pahit. Beras ketan adalah bahan baku yang mewah saat itu, jadi hanya kaum ningrat dan bangsa Eropa saja yang dapat merasakan nikmatnya wajit. Pribumi boleh membuat wajit asalkan disetorkan ke pihak pemerintah kolonial. Juwita dan Uti kemudian mendobrak monopoli kaum ningrat dan pemerintah kolonial, sehingga akhirnya wajit dapat diperjualbelikan bebas ke masyarakat pribumi. 
Pada saat Siti Romlah sedang menunaikan ibadah haji, pembuatan wajit terhenti. Namun kemudian ada keluarga yang membuatnya. Tentu saja dengan resep yang berbeda dari buatan Siti Romlah. Itulah kemudian saat ini ada wajit dengan rasa yang berbeda dari resep asli Siti Romlah yang tentunya dengan penggemar yang berbeda pula. Hingga saat ini telah lahir banyak pembuat wajit, sehingga Desa Cililin dapat dikatakan sebagai kampung wajit dengan 15 sentra industri wajit. Menurut informan, para pengrajin wajit pernah disatukan dalam sebuah wadah organisasi yang disebut KOPAWIT. Juga pernah dibentuk Kelompok Sadar Wisata (Pokdarwis), namun sayang saat penelitian ini KOPAWIT dan Pokdarwis sedang tidak aktif.

Semua wajit memiliki bahan baku utama dan cara pembuatan yang sama. Bahan bakunya berupa ketan putih, gula pasir, gula kawung atau gula aren dan kelapa. Untuk menambah cita rasa biasanya mereka menambahkan susu dan mentega, bahkan ada yang menambahkan durian atau daun pandan.

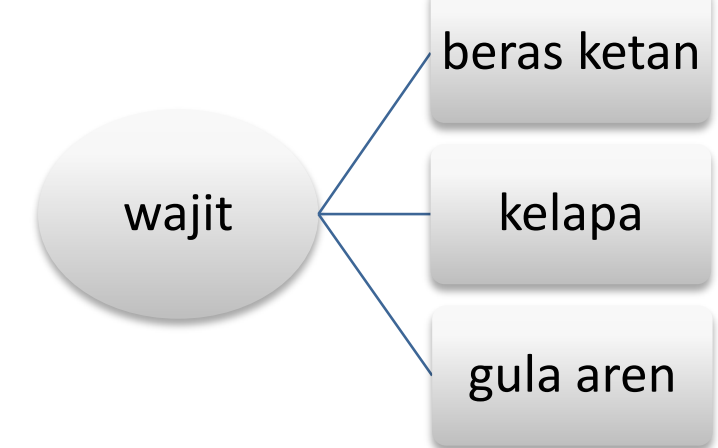

Gambar 2. Bahan baku utama Wajit Cililin.

Sumber : Informan

Proses pembuatan wajit menghabiskan waktu kurang lebih satu hari. Dimulai dari perendaman beras ketan, pengukusan beras ketan, pengolahan tiga bahan utama tersebut, pemasakan secara tradisional yang mengunakan bahan bakar areng dari batok kelapa, sehingga menimbulkan wangi yang khas. Lalu dilakukan 
pembungkusan dengan daun jagung kering. Waktu yang dibutuhkan untuk proses tersebut sekitar empat sampai lima jam. Inilah yang membedakan dari makanan yang lain, yaitu dalam segi kemasannya. Daun jagung yang dimaanfaatkan untuk membungkus memiliki tekstur yang bergerigi dan itu salah satu yang membuat wajit ini bisa bertahan beberapa hari .

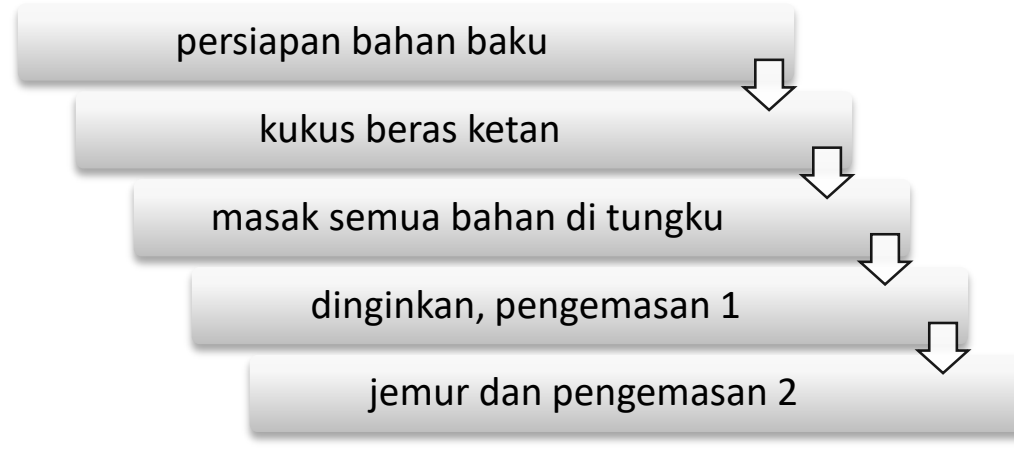

Gambar 3. Tahapan proses pembuatan wajit Sumber : Informan

Adonan wajit yang telah matang dan mencapai kekentalan tertentu, lalu dibiarkan dingin dan dibungkus daun jagung kering. Kemudian dijemur di bawah sinar matahari dengan menggunakan nyiru (nampan) yang terbuat dari anyaman bambu. Setelah dijemur, wajit siap untuk kemasan sekunder. Biasanya kemasan yang digunakan menggunakan plastik berlabel dagang wajit tersebut. Saat ini kemasan rata-rata masih seperti ini. Masih jarang dengan kemasan tersier (penggunaan kemasan ketiga). 


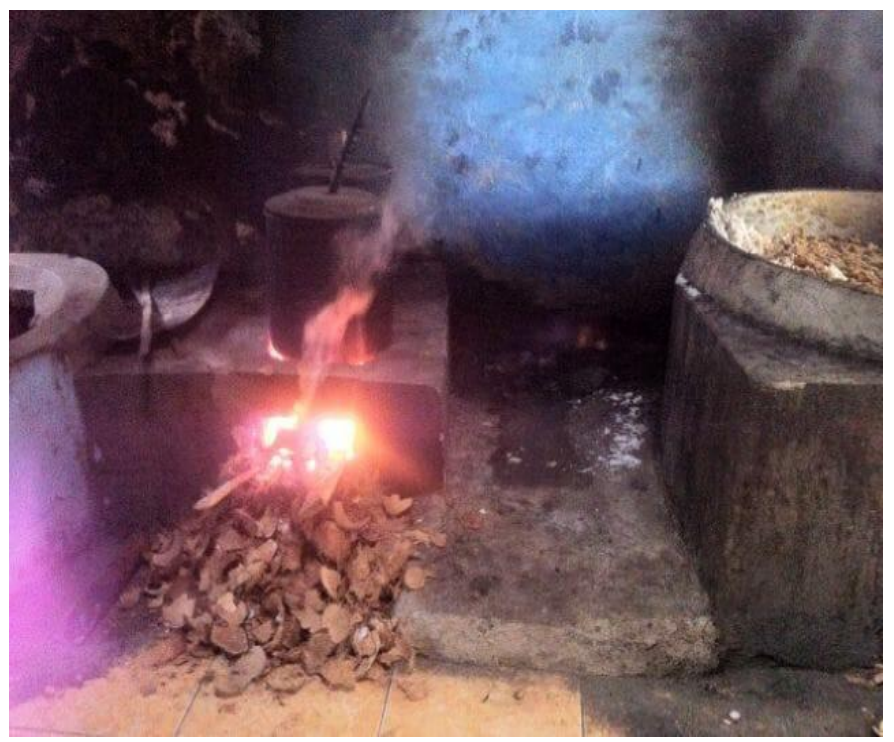

Gambar 4. Proses pengukusan beras ketan setelah direndam beberapa saat. Sumber : Koleksi informan.

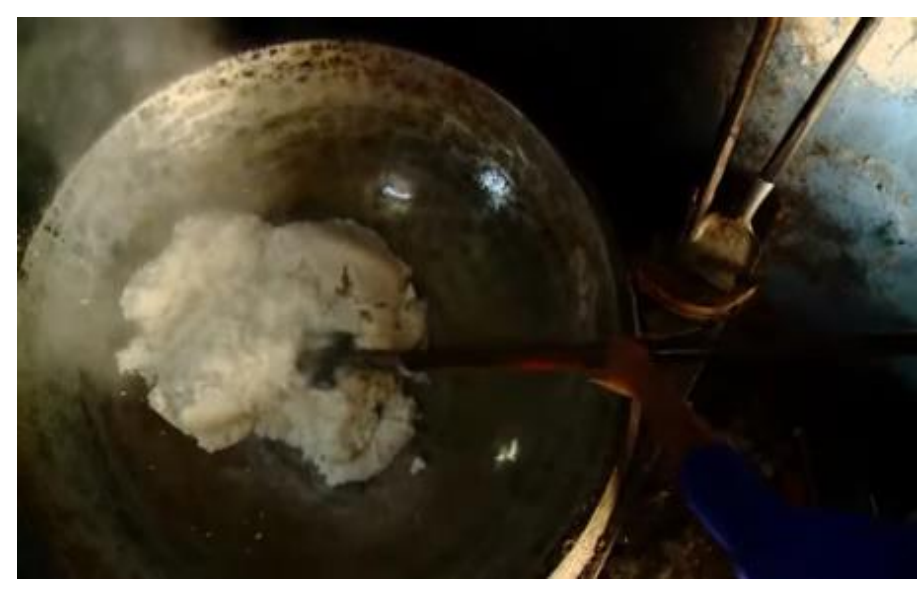

Gambar 5. Pencampuran beras ketan yang telah dikukus dengan bahan lain dalam wajan besar untuk untuk pemrosesan selanjutnya.

Sumber : Koleksi informan. 


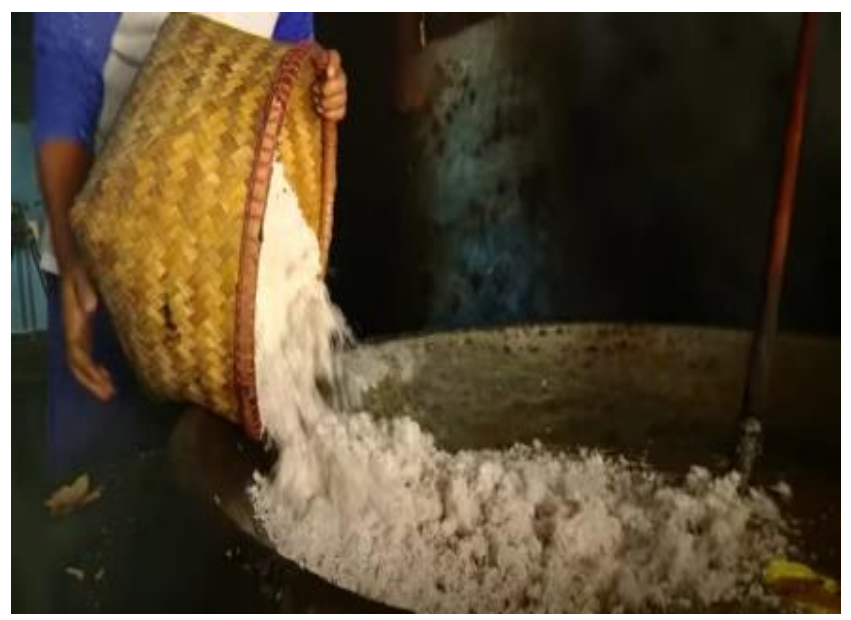

Gambar 6. Memasukkan kelapa parut dalam wajan yang berisi beras ketan dan bahan lainnya.

Sumber : Koleksi informan.

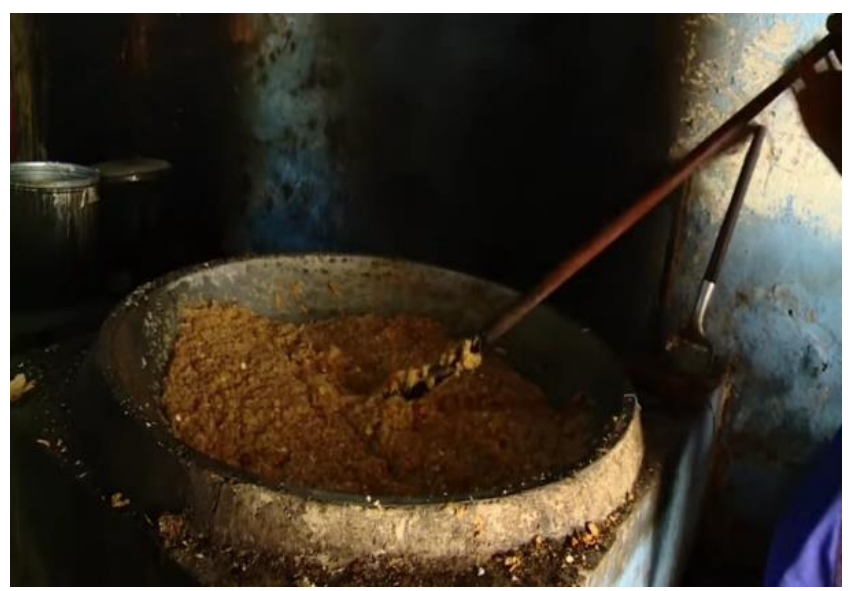

Gambar 7. Beras ketan, kelapa parut, dan gula aren yang telah diaduk menjadi satu dalam wajan.

Sumber : Koleksi informan. 
Arfah Sahabudin, Reiza D. Dienaputra, Awaludin Nugraha

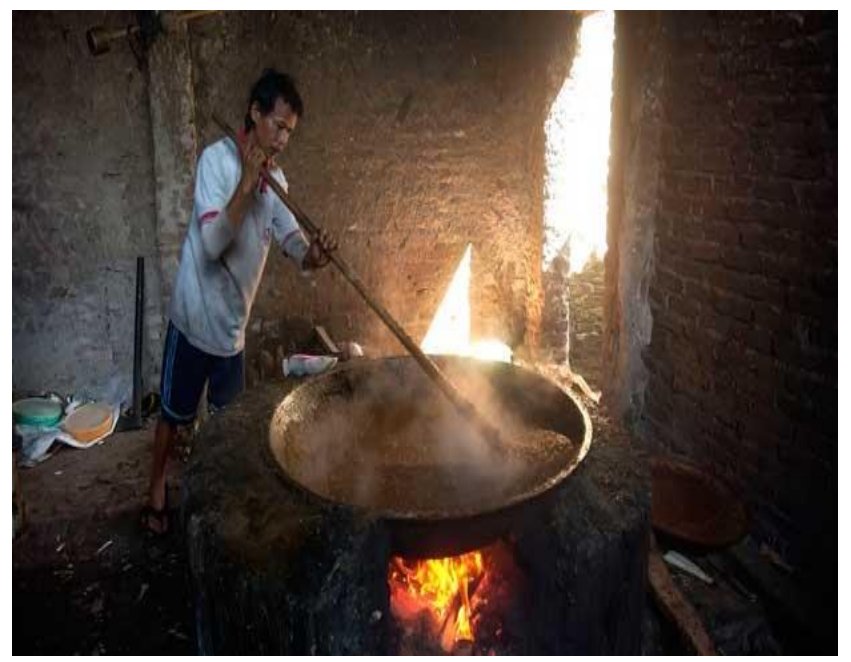

Gambar 8. Proses pematangan wajit.

Sumber : Koleksi informan.

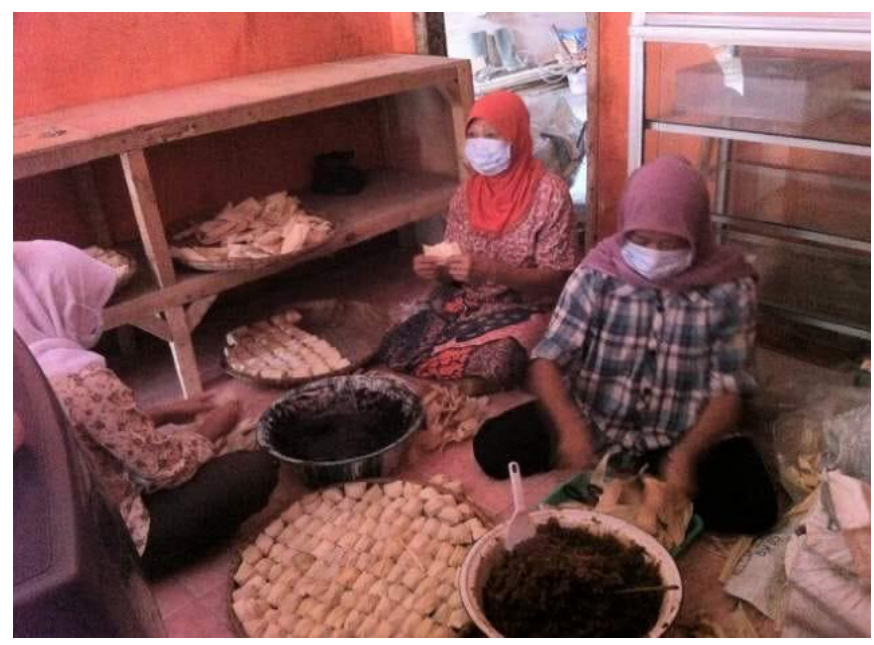

Gambar 9. Proses pembungkusan wajit yang telah dingin. Sumber : Koleksi informan. 


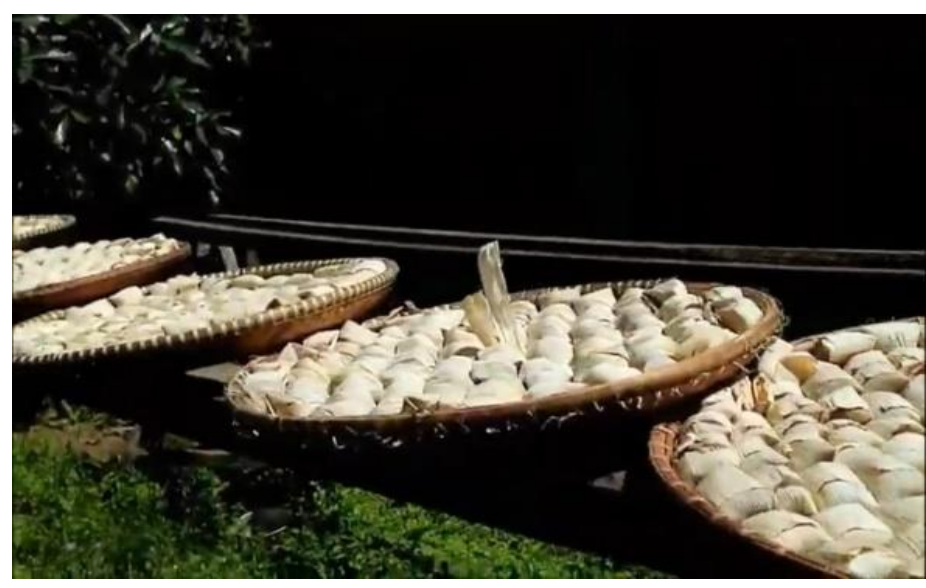

Gambar 10. Proses penjemuran wajit yang telah dibungkus daun jagung. Sumber : Koleksi informan.

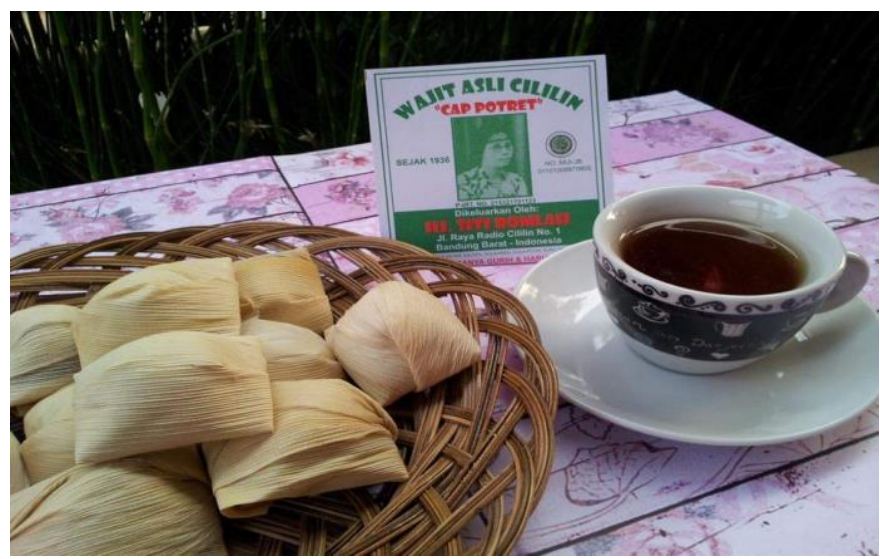

Gambar 11. Wajit Cililin dan secangkir teh hangat. Sumber : Koleksi infroman.

Usia simpan (kadaluarsa) Wajit Cililin rata-rata dua minggu dalam suhu kering, dan satu bulan dalam chiler. Rendahnya usia simpan ini karena Wajit Cililin mengandung kelapa yang mudah tengik atau berjamur dan tidak memakai bahan pengawet. Meski demikian, ada saja pengrajin yang nakal, menambahkan pengawet dan mengurangi kelapanya. Bentuk Wajit Cililin yang asli adalah permukaannya kering dalamnya basah (informan). Usia simpan wajit yang rendah diduga karena adanya perubahan nilai asam lemak bebas, yaitu 14 hari pada kemasan kulit jagung kering (kemasan primer) pada kondisi suhu ruang. 
Proses pembuatan wajit di Desa Cililin yang masih tradisional ini dapat menarik perhatian wisatawan bila dikemas dan disajikan dengan menarik. Misalnya, ruang produksi yang dikemas bersih dan rapi. Pencahayaan yang pas, sirkulasi udara yang baik, serta didukung dengan dekorasi menarik.

Proses pembuatan Wajit Cililin yang unik dan masih tradisional saat ini belum dapat sepenuhnya dinikmati wisatawan. Kondisi tempat proses pembuatan wajit dan toko-toko yang menjual Wajit Cililin masih belum representatif dan belum mendapatkan ruh pariwisata seutuhnya. Sapta Pesona belum terpenuhi yaitu kebersihan, keindahan, kenyamanan, keamanan, ketertiban, keramahtamahan, dan kenangan.

Agar wisatawan dapat menikmati proses pembuatan Wajit Cililin, perlu dilakukan beberapa pembenahan dan perencanaan konsep. Pembenahan tempat produksi agar menarik untuk wisatawan melihat pembuatan wajit sebagai tontonan dan pembelajaran yang menghibur dan informatif. Lalu perencanaan konsep wisatanya, yaitu dalam hal ini peneliti memandang perlu untuk mengembangkan paket wisata edukasi Wajit Cililin yang lengkap dengan sarana pendukungnya.

Dengan begitu, masyarakat tidak hanya sebatas berjualan Wajit Cililin, tetapi mereka juga dapat menawarkan paket wisata edukasi yang di dalamnya terdapat atraksi demo pembuatan wajit, pementasan seni budaya, dan oleh-oleh wajit secara gratis. Target pasarnya minimal adalah anak-anak sekolah. Kemudian fasilitas pendukung ditambahkan seperti ruang tamu, ruang demo/ ruang produksi yang telah ditata rapi, bersih dan indah, gallery wajit/shoping corner, musholla, toilet umum, rumah makan, ATM, dan tempat parkir, sehingga diharapkan juga dapat membuka lapangan usaha dan pekerjaan tambahan bagi masyarakat.

Wisata edukasi merupakan aktivitas pariwisata yang dilakukan wisatawan dan bertujuan utama memperoleh pendidikan dan pembelajaran. Aktivitas wisata 
edukasi dapat menjadi sarana bersosialisasi dan menumbuhkan rasa kebanggaan dan kecintaan terhadap budaya dan bangsa. Untuk memperoleh atraksi pada wisata edukasi Wajit Cililin diperlukan pemandu wisata lokal yang menguasai proses produksi wajit beserta latar belakang sejarah dan budayanya. Pemandu wisata lokal akan menjelaskan mengenai fenomena wajit Cililin, sehingga dapat menjadi tambahan ilmu bagiwisatawan. Dalam konteks wisata edukasi Wajit Cililin, edukasi yang dimaksud adalah penambahan wawasan mengenai Wajit Cililin sebagai khasanah kuliner Nusantara yang ada di Desa Cililin.

Pemandu wisata memiliki peran yang penting bagi kepuasan dan pengalaman berkunjung wisatawan, serta berkewajiban dalam mengarahkan wisatawan dalam menjaga keberlanjutan lingkungan alam dan budaya. Seorang pemandu wisata harus pandai membuat wisatawan menikmati perjalanannya dan tertarik terhadap destinasi wisata serta mendapatkan informasi yang benar, sehingga akan mendorong wisatawan untuk datang lagi atau pun merekomendasikan ke orang lain untuk datang.

Faktor-faktor penghambat pengembangan Wajit Cililin sebagai daya tarik wisata di Desa Cililin, yaitu :

(1) Saat ini wajit hanya dijumpai di toko-toko dan sentra oleh-oleh. Belum ada yang menyajikan proses pembuatannya ke wisatawan yang datang;

(2) Ruangan tempat produksi wajit belum representatif dan layak untuk dijadikan lokasi wisata edukasi di mana proses pembuatan wajit dijadikan tontonan (show attraction) dan sumber pembelajaran wisatawan;

(3) Belum ada sarana pendukung seperti ruangan menerima wisatawan, ruang pengemasan, ruang display wajit cililin dan oleh-oleh lain khas desa Cililin, foto booth dan spot foto, ruang pementasan seni, musholla, kantin, toilet umum, ATM dan tempat parkir; 
(4) Belum ada pemandu wisata lokal atau interpreter yang mampu membuat wisatawan memperoleh pengalaman mengesankan dan memperoleh apa yang mereka cari;

(5) Belum ada prosedur standar operasional pembuatan wajit yang sesuai dengan ketentuan industri rumah tangga ataupun yang sesuai dengan kebutuhan saat ini;

(6) Beberapa pengrajin masih menutup diri untuk perubahan dan masukan;

(7) Masih perlu dilakukan peningkatan kualitas produksi baik kemasan, rasa ataupun umur simpan agar pemasaran dapat lebih jauh jangkauannya, dipasarkan lewat media online, dan layak masuk pasar modern;

(8) Masih minimnya kerjasama kemitraan penyediaan bahan baku, permodalan, dan pemasaran;

(9) Promosi dan pemberitaan media yang kurang intensif dan terencana.

Untuk menciptakan pengembangan sektor pariwisata yang positif dibutuhkan sinergi dari lima pemangku kepentingan utama yang biasa disebut dengan pentahelix, yakni akademisi, pelaku bisnis, pemerintah, komunitas, dan media. Begitu pula untuk mengembangkan potensi proses pembuatan wajit sebagai daya tarik wisata di desa Cililin.

Perguruan tinggi dapat berperan dalam hal:

- Memberikan pelatihan sesuai dengan kebutuhan masyarakat;

- Pendampingan oleh Dosen dan mahasiswa hingga masyarakat desa (wisata) kompeten dalam mengelola desa wisata;

- Membantu memetakan potensi desa;

- Pelatihan manajemen

Pemerintah diharapkan dapat mengupayakan pengembangan wajit Cililin sebagai strategi pemberdayaan masyarakat berupa pembinaan dan pendampingan melalui: 
- Pelatihan pengolahan makanan kemasan, pelatihan keamanan dan ketahanan pangan;

- Fasilitasi dan kemudahan proses perizinan;

- Program pengembangan pemasaran kuliner lokal;

- Program pengembangan kemitraan;

- Program pelatihan SDM;

- Program pendampingan;

- Even-even;

- Dukungan agar Kelompok Sadar Wisata yang sudah ada dapat aktif kembali dan mewujudkan Desa Wisata Wajit Cililin.

Pembinaan dan pendampingan ini harus dilakukan serius dan berkelanjutan, karena meningkatnya kunjungan wisatawan dan berkembangnya daya tarik wisata di Desa Cililin akan meningkatkan ekonomi masyarakat. Para pembuat wajit Cililin harus memperhatikan banyak hal agar proses pembuatan wajit Cililin dapat dinikmati oleh wisatawan. Yang paling utama yang perlu diperhatikan adalah dalam hal kebersihan, keamanan, dan keselamatan pihak-pihak yang melakukan kegiatan di dalamnya. Kebersihan fasilitas dan lingkungan yang tidak dijaga dengan baik, dapat memudahkan bakteri dalam makanan berkembang biak dengan cepat, yang berujung pada penularan penyakit melalui media makanan. Oleh sebab itu, dengan menjaga kebersihan, maka dapat meminimalisasi berkembangnya bakteri pada makanan.

Pengaturan tata letak peralatan masak dan tata letak ruangan, yaitu ruangan bahan baku, ruangan masak, ruangan pembungkusan wajit (daun jagung juga dipastikan sudah dalam keadaan bersih dan kering) tidak dilakukan di lantai, ruang penjemuran wajit terhindar dari pencemaran lingkungan, dan menyiapkan ruangan pengemasan tambahan. Tata letak dan disain ruangan yang unik, bersih, dan instagramable diperlukan untuk menarik perhatian kelompok milenial yang menurut 
survey BPS berjumlah 50\% dari jumlah traveler (BPS, 2016). Namun begitu, perlu diupayakan tetap mempertahankan keaslian dan tradisionalitasnya. Pakaian dan penampilan orang yang membuat wajit juga perlu diperhatikan agar memenuhi standar pengolah makanan.

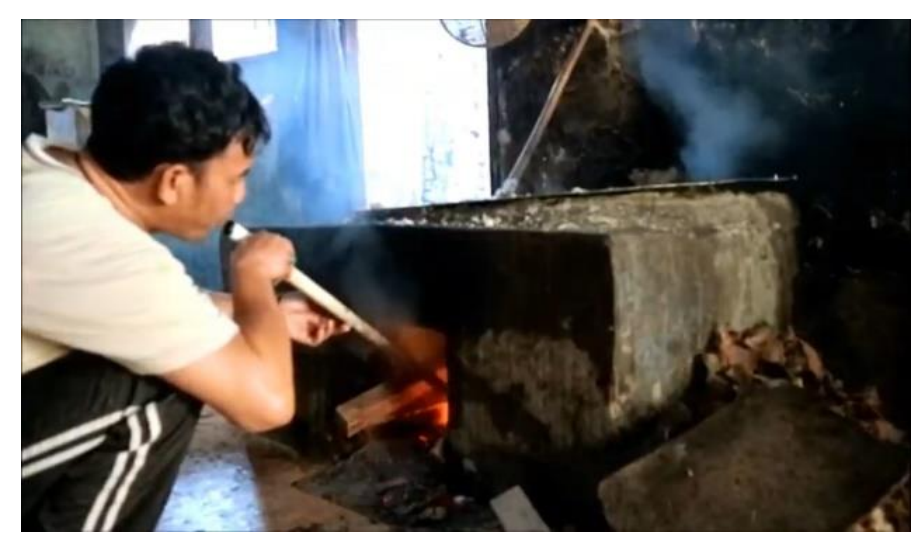

Gambar 12. Teknik MasakTradisional

Sumber : Koleksi informan

Kondisi Desa Cililin yang terdapat banyak pengrajin wajit ini dapat dijadikan sebagai Desa Wisata Wajit, yang di dalamya ada unsur edukasi (wisata eduksi, wisata kulier, atau wisata gastronomi), galeri wajit, wajit shoping corner yang isinya tidak hanya wajit, tapi segala macam makanan dan oleh-oleh khas lain dari Desa Cililin, bahkan cinderamata unik seperti gantungan kunci yang bentuknya wajit, kaos-kaos label dan gambar wajit, dan tentu saja show attraction pembuatan wajit. Semuanya dituangkan dalam paket wisata ke Desa Cililin atau pun paket wisata ke Desa Wisata Wajit Cililin.

Dengan menampilkan atraksi proses pembuatan wajit Cililin, yang sudah dikemas lebih apik dan menarik, tanpa menghilangkan ciri khas dan tradisionalnya, maka wisatawan akan memperoleh pengalaman baru berupa keunikan cara mengolah, alat masaknya, cita rasa, penggunaan bahan lokal tradisional, cara pengolahan, serta kemasan yang bersifat tradisional, sejarah, cerita-cerita, filosofi dari wajit Cililin, bahkan kandungan giji dari wajit Cililin. 


\section{Simpulan dan Saran}

Wajit Cililin yang merupakan hasil karya masyarakat Desa Cililin Kabupaten Bandung Barat adalah aset budaya yang semestinya dilestarikan dan dikembangkan. Proses pembuatannya merupakan potensi daya tarik wisata di desa tersebut yang sangat memungkinkan dikembangkan menjadi atraksi wisata gastronomi. Untuk mewujudkannya sangat diperlukan keterlibatan masyarakat lokal yang menguasai proses produksi serta latar belakang sejarah dan budaya yang mendasarinya. Melalui atraksi wisata gastronomi wisatawan akan mendapat pengetahuan dan pembelajaran tentang seluk beluk wajit Cililin yang sudah lama dikenal masyarakat di luar Desa Cililin. Dengan wisata edukasi itu diharapkan dapat melestarikan wajit Cililin yang sudah melegenda di Jawa Barat. Oleh karena itu, perlu penanganan dan pengelolaan lebih baik lagi dan sedini mungkin yang dilakukan secara terencana dan berkelanjutan.

Dalam mengembangkan wajit Cililin sebagai atraksi wisata gastronomi disarankan melakukan upaya pelestarian melalui program pariwisata dan eveneven kuliner. Upaya tersebut ditunjang oleh proses pembuatan wajit Cililin yang unik sebagai atraksi wisata gastronomi dan wisata edukasi yang dapat dituangkan dalam paket-paket wisata ke Desa Cililin. Perlu dilakukan penambahan jumlah atraksi wisata yang dapat dinikmati wisatawan dan untuk itu diperlukan kajian potensi atraksi wisata yang dimiliki masyarakat Desa Cililin. Untuk mewujudkan dan mengembangkan atraksi wisata gastronomi di Desa Cililin diperlukan kerjasama dengan sesama pemangku kepentingan pariwisata dalam konteks pentahelix. Promosi untuk menyebarluaskan informasi atraksi wisata gastronomi wajit Cililin di Desa Cililin disarankan menggunakan media teknologi terkini. Peningkatan kualitas sumber daya manusia yang terkait dengan proses produksi wajit dan atraksi wisata gastronomi perlu dilakukan melalui pelatihan yang berkelanjutan, terutama dalam hal pengolahan makanan kemasan yang baik dan 
sehat, penerapan Sapta Pesona, pemberdayaan masyarakat melalui Pokdarwis, dan penyadaran akan manfaat lain dari seluk beluk wajit Cililin.

\section{Ucapan Terima Kasih}

Ucapan terima kasih kepada Bapak Syamsul Maarif (Wajit Cililin Cap Potret Hj. Romlah) yang telah membantu memberikan informasi yang penulis butuhkan.

\section{Daftar Pustaka}

Arajuo, E. B., 2016. "Pengembangan Kuliner Lokal Sebagai Daya Tarik Wisata di Dili, Timor Leste", JUMPA, Vol. 3, No.1, pp.15-27.

BPS Kabupaten Bandung Barat, 2017

Firmans Syah , 2017. "Strategi Pengembangan Desa Wisata". Prosiding Seminar Nasional Multi Disiplin Ilmu \& Call For Papers Unisbank Ke-3 (Sendi_U 3) ISBN: 9-789-7936-499-93 335

Hermawan, H., 2017. “Pengaruh Daya Tarik Wisata, Keselamatan dan Sarana Wisata Terhadap Kepuasan serta Dampaknya terhadap Loyalitas Wisatawan : Studi Community Based Tourism di Gunung Api Purba Nglanggeran." Jurnal Media Wisata, 15(1).

Hermawan, H., 2016. “Dampak Pengembangan Desa Wisata Nglanggeran Terhadap Ekonomi Masyarakat Lokal". Jurnal Pariwisata, III(2).

IGB, R. U., Mahadewi, E. N. M. 2012. Metode Penelitian Pariwisata dan Perhotelan. Yogyakarta: Andi Offset.

Jafari, J., Ritchie, J. R. B. 1981. “Toward a Framework for Tourism Education: Problems and Prospects". Annals of Tourism Research, 8(1), 13-34.

J. Damanik, HF. Weber, 2006. Perencanaan ekowisata : Dari teori ke aplikasi. Yogyakarta. Puspar UGM dan Andi

https://ravel.kompas.com/read/2015/11/24/102511227/Ini.5.Destinasi.Wisata.Kuliner. Unggulan.2015

Miles, M. B. dan A. Michael Huberman. 1992. Analisis Data Kualitatif: Buku Sumber tentang Metode-Metode Baru. Jakarta: UI Press.

Maryani, E. 1991, “Pengantar Geografi Pariwisata”. Jurnal IKIP Bandung

Made HU Dewi, Chafid F, M. Baiquni, 2013. "Pengembangan Desa Wisata Berbasis Partisipasi Masyarakat Lokal Di Desa Jatiluwih Tabanan Bali". Jurnal Kawistara, Journal.Ugm.Ac.Id 
M Putra, IBK Astina, 2018. Pemberdayaan Masyarakat Tista Dalam Pengembangan Kuliner Lokal Untuk Mendukung Desa Wisata Tista Kabupaten Tabanan. FM Suarka Perhotelan dan Pariwisata 1 (8), 162-176 | vol: | issue : | 2018

Middleton, Victor. 2001. Marketing in Travel and Tourism. London: Butterworth Heinemann.

Mandra Lazuardi Mochamad Sandy Triady (Tim Studi dan Kementerian Pariwisata Ekonomi Kreatif) Buku Rencana Pengembangan Kuliner Nasional 2015 2019. Penerbit PT. Republik Solusi , 2015

Prasiasa, Dewa Putu Oka. 2013. Destinasi Pariwisata Berbasis Masyarakat. Jakarta: Salemba Humanika.

Putu Sucita Yanthi 2016. “Kontribusi Perempuan Dalam Mengangkat Kulliner Lokal Untuk Mendukung Pariwisata Bali." Desertasi Program Pascasarjana Universitas Udayana

Saeroji, DA Wijaya, 2017. “Pemetaan Wisata Kuliner Khas Kota Surakartaa”. Jurnal Pariwisata Terapan 1 (1), 13-27 | vol: | issue : | 2017

Soekadijo, R. G. 2000. Anatomi Pariwisata Memahami Pariwisata Sebagai Systemic Linkage. Jakarta: PT. Gramedia Pustaka Utama.

Sugiyono. 2011. Metode Penelitian Kuantitatif, Kualitatif dan R\&D. Bandung: Alfabeta.

Sugiyono. 2013. Metode Penelitian Kuantitatif, Kualitatif dan R\&D. Bandung: Alfabeta.

Suryadana, M. V. O. 2015. Pengantar Pemasaran Pariwisata. Bandung Indonesia: Alfabeta.

Tim Pemberdayaan Masyarakat, 2017. Buku Panduan Wisata Edukasi Kampung Tulip. STP ARS Internasional Bandung

Undang-Undang Nomor 10 Tahun 2009 Tentang Kepariwisataan, Sekretariat Negara. Jakarta § 2009. Indonesia.

Virna N, Ervi, (2007). Wisata Kuliner, Bukan Sekedar Wisata Pemuas Nafsu Perut. Wisata Kuliner Maret 2007 Vol. 9 No.1, ISSN 1410-7112.

Yati Haryati (2016). "Studi Motivasi Wisata Kuliner Lokal Di Kota Bandung." Desertasi Program Pascasarjana Universitas Gajahmada. 


\section{Profil Penulis}

Arfah Sahabudin, S.Kom. adalah penggerak dan Pengurus Kelompok Sadar Wisata dan Rintisan Kampung Wisata Pancer di Kelurahan Banten Kecamatan Kasemen Kota Serang Provinsi Banten. Anggota Himpunan Pramuwisata Indonesia (HPI) Provinsi Banten, Ketua Asosiasi Perusahaan Jasa Boga (APJI) Kota Serang, pemilik Luluana Kraft dan Aneka Oleh-oleh Banten dan menjadi bagian dari UMKM Kota Serang. Menyelesaikan S1 di Universitas Gunadarma Depok jurasan Manajemen Informatika. Email : luluana1.arfah@gmail.com

Prof. Dr. Reiza D. Dienaputra, M.Hum. adalah guru besar Fakultas Ilmu Budaya Universitas Padjadjaran dan guru besar pada Prodi Magister Pariwisata Berkelanjutan Sekolah Pascasarjana Universitas Padjadjaran. Saat ini ia menjabat sebagai Ketua Aliansi Strategis Universitas Padjadjaran - Jawa Barat (ASUP JABAR), suatu lembaga yang memfokuskan pada penguatan kapasitas sumber daya manusia di kota/kabupaten di Jawa Barat. Ia banyak menulis artikel di jurnal ilmiah dan media masa berkaitan dengan sejarah visual dan sejarah. E-mail: reizaputra@yahoo.com.

Dr. Awaludin Nugraha, M.Hum. adalah lektor kepala pada Prodi Magister Pariwisata Berkelanjutan Sekolah Pascasarjana Universitas Padjadjaran. Ia menyelesaikan pendidikan tingkat S1 di Jurusan Sejarah Indonesia Universitas Padjadjaran, S2 di Prodi Sejarah Universitas Gadjah Mada, dan S3 di Prodi Doktor Kajian Pariwisata Universitas Gadjah Mada. Ia melakukan penelitian dan menulis artikel pada jurnal ilmiah berkaitan dengan pariwisata berbasis budaya dan kearifan lokal serta sejarah pariwisata. E-mail: awaludin.nugraha@unpad.ac.id. 